\title{
O KUBIE, PRZYJACIELU Z „REYTANA”
}

\author{
Rafał Marszałek
}

We wrześniu 1953 roku stoję na podwórku, na rogu ulic Wiśniowej i Rakowieckiej, w gronie nowych uczniów liceum Reytana. Dołącza do nas szczupły chłopak o charakterystycznym, zaraźliwym uśmiechu. Uśmiechu, który oznacza jedno: radość istnienia.

Oprócz rozmów w latach szkolnych i podczas studiów łączyły nas rowerowe i zimowe wyprawy. Później bywało, że nie widywaliśmy się przez całe lata. Ale zawsze mieliśmy trwały, jakby się kiedyś powiedziało - duchowy kontakt. Co jest o tyle dziwne, że życie każdego z nas poszło zupełnie inną droga. Z jednej strony było to życie społecznika, który wiele dobrego zrobił dla innych; z drugiej - życie szachisty, który skądinąd niewiele wniósł do szachów. A jednak widocznie odbieraliśmy rzeczywistość na tych samych falach. I zastanawiając się nad tym, widzę nie tylko zbieżność topograficzna, te dwieście metrów dzielące nasze domy na Mokotowie, ale jeszcze trzy inne zbieżności. To znaczy: po pierwsze - matecznik rodzinny, po drugie - owo liceum im. Tadeusza Reytana i po trzecie - doświadczenie popaździernikowe.

Ten matecznik rodzinny to najpierw był profesor Zbigniew Karpiński, człowiek wielkiego uroku i kilku drobnych przywar. To on zaraził wirusem spóźnialstwa swego najstarszego syna. Mam przed oczami taki obrazek z późnych lat 50. - przez Aleję Niepodległości do postoju taksówek biegnie wielkimi susami Karpiński - ale jeszcze nie Jakub (który też biegał wielkimi susami), tylko jego tata - znowu gdzieś spóźniony. Więc to zostało w drugim pokoleniu. W mateczniku rodzinnym był jeszcze syn Wojtek, zamknięty w królestwie książek. I wreszcie Marek - najmłodszy z braci - który demonstrował bardzo luźny stosunek do obowiązków szkolnych. Zeszyt upstrzony kleksami zdawał się wróżyć Markowi trudną opozycyjna przyszłość; życiowy optymizm wprowadził go po latach na drogę błyskotliwej kariery rzecznika prezydenta Wałęsy. I jeszcze pani Stanisława, dzielna i pogodna mama trzech budrysów... Ten ich dom otwarty, te spotka- 
nia w rodzinnej przystani nad Jeziorkiem Czerniakowskim - to wszystko składało się na szczególną atmosferę. Powiedziałbym, że było w tym coś z klimatu bohemy.

Z perspektywy czasu bardziej widoczne jest i drugie spoiwo tej biografii Jakuba. W liceum Reytana, od wspaniałych - wymagających, ale ciepłych - przedwojennych profesorów uczyliśmy się wrażliwości na świat, rzetelności poznawczej, dyscypliny wewnętrznej (nie mylić z formalną) i poczucia wspólnoty. Wszystkie te wartości chyba przetrwały. A już na pewno ostatnia z nich, skoro od roku 1977 aż do dzisiaj regularnie spotykamy się w klasowym gronie. Kuba nigdy nie opuszczał tych spotkań. Widać ich potrzebował.

Wreszcie październik 1956. Krótkotrwały, ale jakże szczęśliwy moment otwarcia na świat. O pokolenie od nas starszy Sławomir Mrożek wspominał, jak to ,zakotłowały się w nas Kafki, Hemingwaye, Camusy, Faulknery, Becketty, Sartry i Ioneski w oszałamiającym, pospiesznym pomieszaniu i poplątaniu” (Mrożek 1983: 33-41). Rzeczywiście na progu naszych studiów taka była atmosfera. Jakub łapczywie chłonął świat: jeszcze wczoraj nieznane albo zakazane lektury, pierwsze manifestacje jazzowe, teatr na Tarczyńskiej... Kuba nosił w sobie genetyczny program zainteresowań humanistycznych, który czasem przekuwa się w zdolności artystyczne.

Był ciekaw świata. Wszyscy na tej sali, może poza kilkoma chwalebnymi wyjątkami, jesteśmy egocentrykami. Po trosze wpływa na to hermetyzm uprawianych przez nas dziedzin. Kuba chyba też był egocentrykiem, ale jego ciekawość świata zazwyczaj przeradzała się w empatię, nawet serdeczność w stosunku do otoczenia. Te czułki wystawione w stronę bliźnich pozwalały, wbrew przeciwnościom losu, smakować urodę życia.

W tym punkcie jednak nie mogę powstrzymać się od dygresji. Otóż jedyna pretensją do mego świętej pamięci przyjaciela jest to, że w jego szerokie horyzonty nie wpisywał się sport. Karpiński nie uznawał sportu za ważną dziedzinę życia. Sukcesów sportowych nie znał ani nie szanował, osadzenia sportu w kulturze nie dostrzegał. Stał po stronie takich dziwaków jak Antoni Słonimski, który kiedyś w „Kronikach tygodniowych” natrząsał się z publiki zapatrzonej w mocarne uda kolarza Więcka, pierwszego zwycięzcy Tour de Pologne. No, ale każdy ma swoje wady, o czym i Państwo tutaj napomykali.

Jakie miejsce w życiu Jakuba zajmowała polityka? Ważne, ale przecież nie zaprogramowane. Z tego, co wiem i pamiętam z najmłodszych lat, Kuba uważał komunizm przede wszystkim za bzdurę. Istnieje sprzeczność między bardzo suchym, akademickim językiem jego książki o ustroju 
komunistycznym w Polsce, a olśniewającymi kartami Taternictwa niz̨innego. Tytuł tej książki mówi właściwie wszystko o „taterniku” Jakubie Karpińskim i ustroju komunistycznym. Po co, zamiast tego, pisać wielką, uczoną księgę? Dla stopnia naukowego, dla oświecenia maluczkich, dla przekonania przekonanych czy nieprzekonanych? Tak czy inaczej, z naszego ówczesnego punktu widzenia to była zwyczajnie jakaś bzdura. Jeśli więc Państwo tutaj mówili o podziale na partyjnych i bezpartyjnych, to pamiętam, że tych partyjnych na uniwersytecie traktowało się nie jak wrogów, nawet niekoniecznie jak arywistów (którymi często bywali), ale jak jakichś odmieńców.

Kiedy mówi się o Karpińskim jako o naukowcu, który nie do końca się spełnił, to myślę sobie, że zmarnował się raczej jako pisarz. À propos Taternictwa niæinnego. Gdyby tak sobie odpuścił i w osobnym reportażu literackim opisał swoją odyseję więzienna, począwszy od tego, jak siedzi na wieżyczce i liczy kapcie, a skończywszy na bogatszej charakterystyce współtowarzyszy niedoli, to tym bardziej byłaby wspaniała opowieść. On fascynował się groteskowymi realiami i mówił: „Słuchaj, nie przesadzajmy, nie było tak strasznie. Oto siedzę i liczę buty... No coś niebywałego!”. Więc traktował to jako życiowa przygodę, oczywiście z całą dwuznacznością takiego określenia. Niewielu było takich ludzi jak on, gdy chodzi o odwagę i męską konsekwencję. Bo nie wszyscy mężczyźni są męscy, a Kuba, tak fizycznie kruchy, był bardzo męskim mężczyzną.

Chciałbym Państwu zwrócić uwagę na to, co rzadko bywa podnoszone: na stronę językowa jego twórczości. Strona językowa doskonale oddaje jego sposób myślenia. Nie sądzę, żeby odyseja więzienna i uwikłanie w politykę zasadniczo zmieniły jego sposób patrzenia na świat. Antykomunizm i intelektualizm wyniósł z domu. Natomiast co do samego zapisu rzeczywistości, to niewiele można znaleźć odpowiedników w jego macierzystej, socjologicznej dziedzinie. Interesujące są te przykłady myślenia Karpińskiego, które odnoszą się do zdziwienia jednych (zwłaszcza młodych) tym, że można w jakiś osobliwy sposób być przywiązanym nostalgicznie do PRL-u - i przeciwnie, przykłady myślena tych drugich, którzy dorastali i żyli w PRL-u, w którym można widzieć tylko czas opresji i terroru, skoro przecież były maje i czerwce, były kwiaty, były dziewczyny... Jak to pogodzić? A Jakub to pogodził w czterech zdaniach, mówiąc:

Doświadczenie komunizmu realnego jako o k r e s u, jako okresu w historii Polski, obejmuje wszystko, co się wtedy działo. Jest to znacznie więcej niż doświadczenie komunizmu jako systemu 
sprawowania władzy. Nie wszystko w okresie komunizmu, trwania komunizmu, było komunizmem. Niektórzy o tym pamiętają, inni nie. Ci drudzy skłonni są mylić Irenę Santor z Julią Brystygierową.

Krótko i zwięźle. I o co się tu spierać? Tylko cztery zdania. Karpiński rzuca je en passant, z dala od wytartych schematów. Nieszablonowo pisze też o elicie władzy. Zauważa, że w tamtych czasach elita władzy nie pokrywała się z elitą dochodów, prestiżu ani wykształcenia. Sąd tylko pozornie oczywisty, skoro tak bardzo zaprzeczający potocznym wyobrażeniom. A później, w polemice z Milovanem Djilasem, Karpiński podkreśla, że przywileje w ogóle nie są dobrym tropem do wyodrębnienia elity władzy. I daje następujący przykład, który swoją lekkością tonu pewnie zgorszył niektórych badaczy: „Udogodnienia, które miał w Polsce Edward Gierek, nie były zapewne większe od tych, z jakich korzystali uczestnicy półlegalnego życia gospodarczego. A to dlatego, że Edward Gierek nie miał prywatnego czasu w nadmiarze".

Czasem również znajdujemy w tym pisarstwie określenia, które wydają się prawie tautologiczne, a nagle odkrywa się w nich podwójne dno. Na przykład:

Roman Ingarden napisał szkic Czego nie wiemy o wartościach. Wielu rzeczy nie wiemy. Wydaje się jednak za rozsądne uznać, że wartości są wartościami czegoś. Przysługują rzeczom, ludziom, ich czynom, skomplikowanym urządzeniom społecznym. Jeśli teksty ewangeliczne głosza, że coś być powinno, to uznają to za wartościowe.

Gdy wmyślimy się w tę niby prostą tezę, to z niepokojem odkrywamy, że moga z niej wynikać bardzo różne praktyczne konsekwencje.

Ostatnie, co mam do przypomnienia, gdy idzie o odpowiedniość pisania i myślenia, to jest mail do mnie, mieszkającego wtedy w Słowenii, wysłany przez Jakuba na kilka dni przed jego śmiercią. Siedmiozdaniowy mail, który brzmiał następująco:

Ze zdrowiem są kłopoty. Jestem osłabiony. Spędzam dużo czasu w Centrum Onkologii, gdzie długo oczekuje się na lekarza, bo jest mnóstwo pacjentów. Lekarz jest kompetentny. Przepisuje mi

${ }^{1}$ Cytaty dla celów wystapienia zostały dobrane losowo i dziś nie potrafię odnaleźć, z jakich publikacji pochodza - przyp. aut. 
w formie kroplówek rozmaite leki. Przyjmowanie tych kroplówek odbywa się w warunkach komfortowych, w małych salkach. Trwa to często ponad dwie godziny, które spędzam, przygotowując nowe wydanie podręcznika metodologii.

To było ostatnie, co napisał. W tekście pojawiają się tylko dwa ocenne przymiotniki. O kompetentnych lekarzach i o komfortowych warunkach w szpitalu. Tylko te dwa przymiotniki. Coś niesamowitego.

Bibliografia:

/// Mrożek S. 1983. Popiół? Diament?, „Kultura”, nr 1, s. 33-41. 